Article

\title{
Scenario Analysis of Nutrient Removal from Municipal Wastewater by Microalgal Biofilms
}

\author{
Nadine C. Boelee ${ }^{1,2,3, *}$, Hardy Temmink ${ }^{1,2}$, Marcel Janssen ${ }^{3}$, Cees J. N. Buisman ${ }^{1,2}$ and \\ René H. Wijffels ${ }^{3}$
}

1 Wetsus - Centre of Excellence for Sustainable Water Technology, P.O. Box 1113, Leeuwarden 8900 CC, The Netherlands; E-Mails: hardy.temmink@wur.nl (H.T.); cees.buisman@wur.nl (C.B.)

2 Sub-department of Environmental Technology, Wageningen University, P.O. Box 8129, Wageningen 6700 EV, The Netherlands

3 Bioprocess Engineering, Wageningen University, P.O. Box 8129, Wageningen 6700 EV, The Netherlands; E-Mails: marcel.janssen@wur.nl (M.J.); rene.wijffels@wur.nl (R.W.)

* Author to whom correspondence should be addressed; E-Mail: nadine.boelee@wetsus.nl; Tel.: +31-58-2843000; Fax: +31-58-2843001.

Received: 27 February 2012; in revised form: 27 March 2012 / Accepted: 13 April 2012 / Published: 27 April 2012

\begin{abstract}
Microalgae can be used for the treatment of municipal wastewater. The application of microalgal biofilms in wastewater treatment systems seems attractive, being able to remove nitrogen, phosphorus and COD from wastewater at a short hydraulic retention time. This study therefore investigates the area requirement, achieved effluent concentrations and biomass production of a hypothetical large-scale microalgal biofilm system treating municipal wastewater. Three scenarios were defined: using microalgal biofilms: (1) as a post-treatment; (2) as a second stage of wastewater treatment, after a first stage in which COD is removed by activated sludge; and (3) in a symbiotic microalgal/heterotrophic system. The analysis showed that in the Netherlands, the area requirements for these three scenarios range from 0.32 to $2.1 \mathrm{~m}^{2}$ per person equivalent. Moreover, it was found that it was not possible to simultaneously remove all nitrogen and phosphorus from the wastewater, because of the nitrogen:phosphorus ratio in the wastewater. Phosphorus was limiting in the post-treatment scenario, while nitrogen was limiting in the two other scenarios. Furthermore, a substantial amount of microalgal biomass was produced, ranging from 13 to $59 \mathrm{~g}$ per person equivalent per day. These findings show that microalgal biofilm systems hold large potential as seasonal wastewater treatment systems and that it is worthwhile to investigate these systems further.
\end{abstract}


Keywords: algal biofilm; nitrogen removal; phosphorus removal; effluent polishing; wastewater treatment

\section{Abbreviations}

COD—Chemical Oxygen Demand

MTR-Maximum Tolerable Risk

PAR-Photosynthetic Active Radiation

PE-Person Equivalent
SRT-Sludge retention Time

VSS - Volatile suspended solids

WWTP_Wastewater Treatment Plant

\section{Introduction}

The conventional treatment of municipal wastewater consists of activated sludge processes with a combination of nitrification and denitrification and biological or chemical phosphorus removal. However, other treatment systems are also used, including systems based on microalgae, eukaryotic microorganisms and prokaryotic cyanobacteria that carry out oxygenic photosynthesis [1]. Microalgae have a high affinity for nitrogen $(\mathrm{N})$ and phosphorus $(\mathrm{P})$, illustrated by the low values reported for half-saturation constants, ranging from 0.56 to $3094 \mu \mathrm{g} \mathrm{N} / \mathrm{L}$, and from 0.001 to $81.9 \mu \mathrm{g} \mathrm{P} / \mathrm{L}$ [2-5]. Microalgae can either grow in suspension (phytoplankton) or on substrata (benthic) in biofilms [6]. Microalgal biofilms are attached microbial consortia of phototrophs and chemotrophs entrapped in an exopolymeric matrix, and are omnipresent in aquatic environments [7,8]. Although not given a lot of attention, microalgal biofilms systems could form interesting wastewater treatment systems. A microalgal biofilm system can operate at short hydraulic retention times due to the ability of the biofilm to retain the biomass. It is also expected that, in contrast to suspended microalgal systems, little or no separation of microalgae and water is required before discharging the effluent $[9,10]$. Furthermore, no mixing is needed in the system, resulting in a lower energy requirement than for suspended systems.

Algal biofilms systems can be composed of large biofilm panels over which the wastewater flows. These panels can either be placed horizontally, at an angle like the algal turf scrubber [11], or vertically in rows like the twin layer system [12]. Such microalgal biofilms may be used at different stages of the wastewater treatment. A first scenario is using microalgal biofilms as a post-treatment system. In light of the EU Water Framework Directive objective to obtain good chemical and ecological status for all surface waters by 2015 , this can be an interesting concept. The high affinity of microalgae for $\mathrm{N}$ and $\mathrm{P}$ and the lack of requirement of an organic carbon source are advantages over currently available post-treatment systems. A microalgal biofilm can also be used to remove $\mathrm{N}$ and $\mathrm{P}$ after a highly loaded activated sludge system. The microalgal biofilm then serves as an alternative for nitrification and denitrification and chemical or biological $\mathrm{P}$ removal. This scenario holds the advantages of a higher net heterotrophic biomass yield, and a lower energy input for aeration compared to a conventional wastewater treatment system.

A third option is applying an algal-bacterial biofilm to treat the wastewater directly. This scenario makes use of a symbiotic relationship that may develop when using microalgae and heterotrophs 
together. During this symbiosis the microalgae produce oxygen $\left(\mathrm{O}_{2}\right)$ that is needed by aerobic heterotrophs, and the carbon dioxide $\left(\mathrm{CO}_{2}\right)$ that is released by these heterotrophs is in turn used by the microalgae. In this manner no external $\mathrm{O}_{2}$ supply is needed, which saves the energy otherwise required for aeration of the activated sludge system.

Previous studies have shown that microalgal biofilms systems can achieve good removal of $\mathrm{N}$ and $\mathrm{P}$ from wastewater. Removal capacities over $90 \%$ were measured for ammonium $\left(\mathrm{NH}_{4}{ }^{+}\right)$, nitrate $\left(\mathrm{NO}_{3}{ }^{-}\right)$ and over $80 \%$ for phosphate $\left(\mathrm{PO}_{4}{ }^{3-}\right)$ [12-14], and up to $75 \%$ of the Chemical Oxygen Demand (COD) was removed from diluted swine manure in an algal-bacterial biofilm [14]. However, the feasibility of the application of microalgal biofilms in wastewater treatment will be determined by more factors than the removal capacity. These factors include the achieved effluent concentrations, biomass production and the area requirement. Especially the latter is a point of concern, as algal systems are known for their relatively large area requirement. Unfortunately, little is known about these aspects of microalgal biofilms and how the three different scenarios mentioned above compare.

This study aims to get insight in the feasibility of using microalgal biofilms for municipal wastewater treatment. A scenario analysis will be performed for the three different concepts of using microalgal biofilms in municipal wastewater treatment. This analysis compares the area requirement, achieved effluent concentrations and biomass production under the conditions of municipal wastewater treatment in the Netherlands. In addition, this study seeks to determine what knowledge is still lacking in order to be able to make a final conclusion on the feasibility of microalgal biofilms in wastewater treatment.

\section{Material and Methods}

\subsection{Scenarios}

Three different scenarios were defined in which microalgae are integrated in a municipal wastewater treatment plant (WWTP), as shown in Figure 1.

In Scenario 1 the microalgal biofilm system is used as a post-treatment system for effluent from an activated sludge process. In Scenario 2 the first stage of wastewater treatment removes the bulk of the COD. Nitrification is prevented in this stage by operating at a short sludge retention time (SRT; 2.5 days). The second stage consists of a microalgal biofilm system removing $\mathrm{N}$ and $\mathrm{P}$. In contrast to Scenario 1, $\mathrm{N}$ is mainly present as $\mathrm{NH}_{4}{ }^{+}$rather than $\mathrm{NO}_{3}{ }^{-}$. In Scenario 3 the microalgae are used in a symbiotic process of algae and bacteria. $\mathrm{N}$ is removed by combined nitrification and denitrification and via assimilation by microalgae, COD is removed by heterotrophs, and $\mathrm{P}$ is mainly assimilated by microalgae.

In all scenarios the target effluent values were $2.2 \mathrm{mg} / \mathrm{L}$ total $\mathrm{N}$ and $0.15 \mathrm{mg} / \mathrm{L}$ total $\mathrm{P}$. These values are the maximum tolerable risk (MTR) guidelines which are used by the Dutch water boards, as the classification of the good chemical and ecological status of surface water of the Water Framework Directive is not yet known. 
Figure 1. Schematic overview of the three different scenarios of using microalgal biofilms in municipal wastewater treatment. The incoming wastewater and target effluent MTR values of $2.2 \mathrm{mg} / \mathrm{L} \mathrm{N}$ and $0.15 \mathrm{mg} / \mathrm{L} \mathrm{P}$ are equal for all scenarios. The sludge retention time (SRT) is shown for the activated sludge compartments of Scenarios 1 and 2.

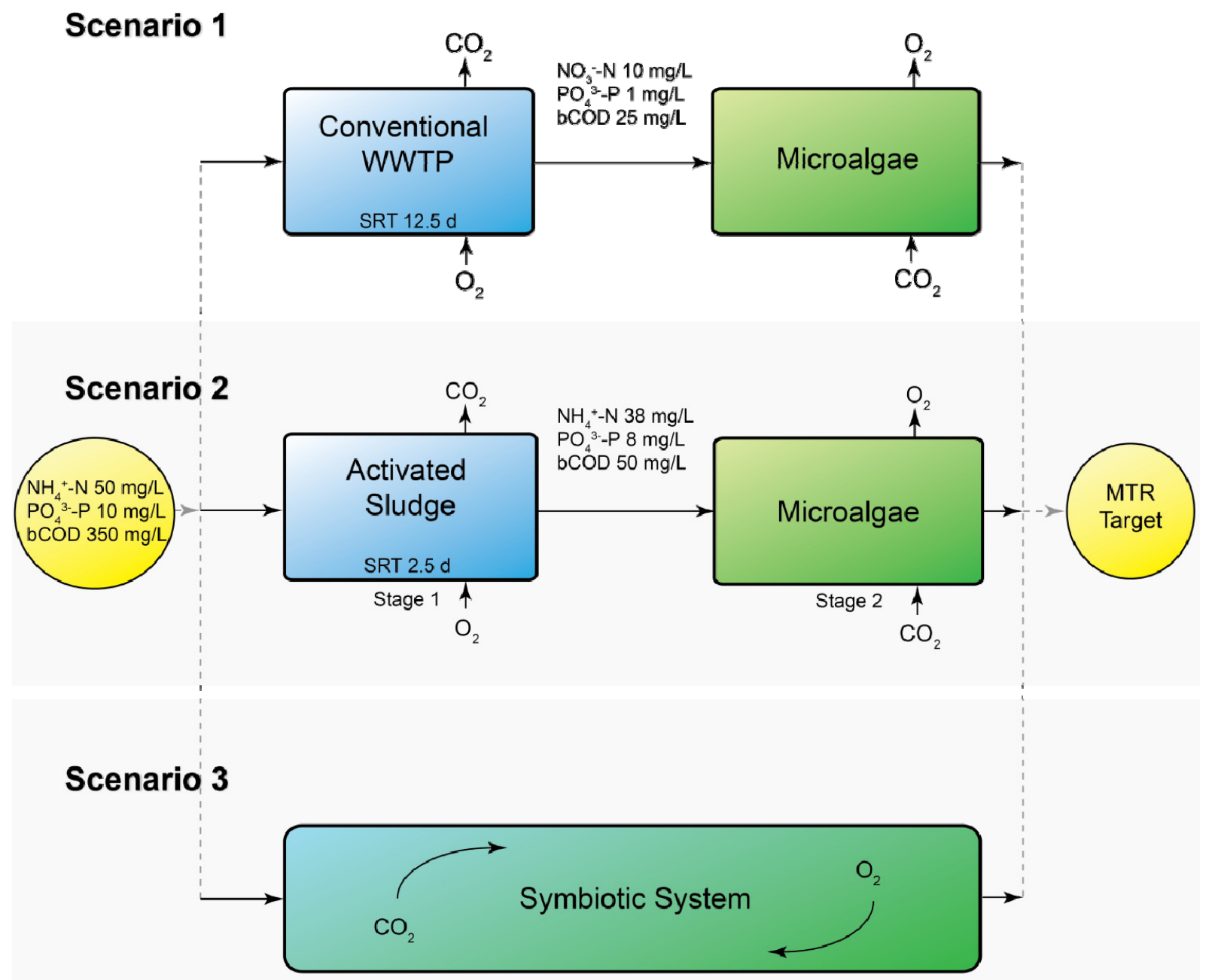

\subsection{Calculations and Parameters}

\subsubsection{Microalgae}

The WWTP in this study was located in the Netherlands and receives wastewater from 100,000 inhabitants producing $130 \mathrm{~L}$ per person equivalent (PE) per day. In the Netherlands, microalgal systems offer the highest potential at tourist locations during the period late spring-early autumn, when an increased wastewater production is accompanied by the highest irradiation of the year. Therefore, only the period late spring-early autumn was considered in this analysis, corresponding with the tourist season. The microalgal biofilm system therefore receives irradiation summed over the months May until October. The microalgae utilize $43 \%$ of this irradiation, equivalent to the photosynthetic active radiation (PAR, 400-700 nm). The variation of irradiance during the day and over these months has not been taken into account, but will be discussed subsequently. The summed irradiation was equal to $4773 \mathrm{~mol}$ photons $/ \mathrm{m}^{2}$ (see Appendix A). 
An important parameter of the microalgal system is the quantum requirement of the photosynthetic process. This is the efficiency with which the microalgae take up light energy and convert it to chemical energy, i.e., new biomass, while releasing $\mathrm{O}_{2}$. Under low light intensities, approximately 10 PAR photons are required for the liberation of one molecule of $\mathrm{O}_{2}[15,16]$. At higher light intensities, photosaturation takes place and part of the absorbed light is lost in the form of heat. Considering this photosaturation effect, a vertical positioning of the microalgal biofilm system is proposed and a minimal quantum requirement of 20 PAR photons per $\mathrm{O}_{2}$ is envisioned [17]. This corresponds to a maximum oxygen quantum yield $\left(Q Y_{O_{2}}\right)$ of $0.05 \mathrm{O}_{2} /$ photon. With $Q Y_{O_{2}}$ the amount of $\mathrm{O}_{2}$ produced per photons received per $\mathrm{m}^{2}$ of ground area is calculated:

$$
R_{o, A, a l g a e}=Q Y_{O_{2}} \cdot P F D\left[\mathrm{~mol} / \mathrm{m}^{2} / \mathrm{d}\right]
$$

with $\mathrm{R}_{\mathrm{O}, \mathrm{A} \text {,algae }}$ the areal oxygen production by microalgae $\left[\mathrm{mol} / \mathrm{m}^{2} / \mathrm{d}\right]$; PFD the photon flux density [mol photons $\left./ \mathrm{m}^{2} / \mathrm{d}\right]$.

The following stoichiometrical reactions are used for microalgae, with either nitrate (assumed in Scenario 1) or ammonium (assumed in Scenarios 2 and 3) as nitrogen source:

$$
\begin{gathered}
\mathrm{CO}_{2}+0.94 \mathrm{H}_{2} \mathrm{O}+0.12 \mathrm{NO}_{3}{ }^{-}+0.01 \mathrm{H}_{2} \mathrm{PO}_{4}{ }^{-} \rightarrow \mathrm{CH}_{1.78} \mathrm{O}_{0.36} \mathrm{~N}_{0.12} \mathrm{P}_{0.01}+1.42 \mathrm{O}_{2}+0.13 \mathrm{OH}^{-} \\
\mathrm{CO}_{2}+0.70 \mathrm{H}_{2} \mathrm{O}+0.12 \mathrm{NH}_{4}^{+}+0.01 \mathrm{H}_{2} \mathrm{PO}_{4}{ }^{-} \rightarrow \mathrm{CH}_{1.78} \mathrm{O}_{0.36} \mathrm{~N}_{0.12} \mathrm{P}_{0.01}+1.18 \mathrm{O}_{2}+0.11 \mathrm{H}^{+}
\end{gathered}
$$

The areal amount of biomass produced $\left(\mathrm{P}_{\mathrm{x}, \mathrm{A}, \mathrm{algae}}\right)$ is calculated with Equation 2 or $3 ; 1.42 \mathrm{~mol} \mathrm{O}_{2}$ coincides with $1 \mathrm{~mol}$ of biomass (on C-basis) in case of $\mathrm{NO}_{3}{ }^{-}$uptake or $1.18 \mathrm{~mol} \mathrm{O}_{2}$ with 1 mol of biomass in case of $\mathrm{NH}_{4}^{+}$uptake. This biomass is assumed to be present in a biofilm kept at optimal thickness through regular harvesting of the biofilm. Keeping the biofilm at this thickness will reduce respiration losses and ensure an optimal nutrient uptake capacity.

It is expected that the microalgal biofilm will be composed of a mixed culture of microalgae, due to varying conditions with respect to temperature, and $\mathrm{N}$ and $\mathrm{P}$ concentrations. We assumed an average microalgal biomass composition for this mixed culture, of $7.8 \% \mathrm{~N}$ and $1.4 \% \mathrm{P}(\mathrm{w} / \mathrm{w}$, based on algal biomass of $\mathrm{CH}_{1.78} \mathrm{O}_{0.36} \mathrm{~N}_{0.12} \mathrm{P}_{0.01}$ ) [18-20]. With the amount of biomass produced known and the fraction of $\mathrm{N}$ and $\mathrm{P}$ present in the biomass, the uptake of $\mathrm{N}$ and $\mathrm{P}$ from the wastewater is calculated. The following calculation shows the uptake of $\mathrm{N}$, but the calculation of the $\mathrm{P}$ uptake is equivalent:

$$
R_{N, A, \text { algae }}=R_{x, A, \text { algae }} \cdot f_{N, \text { algae }}\left[g / \mathrm{m}^{2} / d\right]
$$

with $\mathrm{R}_{\mathrm{N}, \mathrm{A} \text {,algae }}$ the areal $\mathrm{N}$ uptake rate by microalgae $\left[\mathrm{g} / \mathrm{m}^{2} / \mathrm{d}\right]$; $\mathrm{P}_{\mathrm{x}, \mathrm{A} \text {,algae }}$ the areal microalgal biomass production rate $\left[\mathrm{g} / \mathrm{m}^{2} / \mathrm{d}\right]$ and $\mathrm{f}_{\mathrm{N} \text {,algae }}$ the fraction of $\mathrm{N}$ in the microalgal biomass $[\mathrm{g} / \mathrm{g}]$.

Using the desired amount of $\mathrm{N}$ or $\mathrm{P}$ removed, the area was calculated as:

$$
A=\frac{Q \cdot\left(N_{\text {in }}-N_{\text {out }}\right)}{R_{N, A, \text { algae }}}\left[m^{2}\right]
$$

with $A$ the area $\left[\mathrm{m}^{2}\right]$ and $\mathrm{Q}$ the flowrate $\left[\mathrm{m}^{3} / \mathrm{d}\right]$.

\subsubsection{Heterotrophs}

It was assumed that biomass production in the activated sludge process is only accounted for by the heterotrophic biomass converting COD. The following formula is used [21]: 


$$
P_{x, \text { sludge }}=Q \cdot Y_{\text {sludge }} \cdot \frac{\left(C O D_{b, \text { in }}-C O D_{b, \text { out }}\right)}{1+k_{d} \cdot S R T} \cdot\left(1+f_{d} \cdot k_{d} \cdot S R T\right)[g V S S / d]
$$

with $\mathrm{P}_{\mathrm{x}, \text { sludge }}$ the sludge production $\left[\mathrm{g}\right.$ VSS/d]; $\mathrm{Y}_{\text {sludge }}$ the biomass yield [g VSS/g bCOD], SRT the sludge retention time [d]; $f_{d}$ the fraction remaining as cell debris $\left[g\right.$ VSS/g VSS] and $k_{d}$ the decay coefficient $\left[\mathrm{d}^{-1}\right]$.

The sludge in the WWTP was assumed to have an average composition of $12 \% \mathrm{~N}$ and $2 \% \mathrm{P}$ (w/w based on sludge biomass of $\mathrm{C}_{1} \mathrm{H}_{1.4} \mathrm{O}_{0.4} \mathrm{~N}_{0.2}$ ) [21]. With the amount of biomass produced known and the fraction of $\mathrm{N}$ and $\mathrm{P}$ present in the biomass, the uptake of $\mathrm{N}\left(\mathrm{R}_{\mathrm{N}, \text { sludge }}\right)$ and $\mathrm{P}$ from the wastewater is calculated. Calculation shown here for $\mathrm{N}$ :

$$
R_{N, \text { sludge }}=R_{x, \text { sludge }} \cdot f_{N, \text { sludge }}[g / d]
$$

Additional calculations of $\mathrm{O}_{2}$ and $\mathrm{CO}_{2}$ production and consumption, and a list of all parameters can be found in Appendix A.

\section{Results}

Table 1 shows the area requirement of the microalgal biofilm and the corresponding effluent concentrations for the different scenarios. The area requirements are based on the calculated uptake capacities of $1.85 \mathrm{~g} \mathrm{~N} / \mathrm{m}^{2} / \mathrm{d}$ and $0.34 \mathrm{~g} \mathrm{P} / \mathrm{m}^{2} / \mathrm{d}$ in Scenario 1 and $2.2 \mathrm{~g} \mathrm{~N} / \mathrm{m}^{2} / \mathrm{d}$ and $0.41 \mathrm{~g} \mathrm{P} / \mathrm{m}^{2} / \mathrm{d}$ in Scenarios 2 and 3. The area requirement of the post-treatment system of Scenario 1 is the smallest with $0.32 \mathrm{~m}^{2} / \mathrm{PE}$, followed by the symbiotic system of Scenario 3 requiring $0.76 \mathrm{~m}^{2} / \mathrm{PE}$. The large area requirement of $2.1 \mathrm{~m}^{2} / \mathrm{PE}$ of Scenario 2 in comparison to Scenarios 1 and 3 was due to the larger amount of $\mathrm{N}$ that needed to be assimilated by the microalgae in this scenario.

Table 1. The required ground area and effluent concentrations of $\mathrm{N}$ and $\mathrm{P}$ of a microalgal biofilm system treating wastewater from 100,000 inhabitants in the Netherlands during May to October for the three different scenarios.

\begin{tabular}{cccc}
\hline Scenario & $\begin{array}{c}\text { Area requirement } \\
\left(\mathbf{m}^{\mathbf{2}} / \mathbf{P E}\right)\end{array}$ & $\begin{array}{c}\text { Effluent total N } \\
(\mathbf{m g} / \mathbf{L})\end{array}$ & $\begin{array}{c}\text { Effluent total P } \\
(\mathbf{m g} / \mathbf{L})\end{array}$ \\
\hline Scenario 1 & 0.32 & 5.39 & 0.15 \\
Scenario 2 & 2.10 & 2.20 & 1.40 \\
Scenario 3 & 0.76 & 2.20 & 6.07 \\
\hline
\end{tabular}

The limiting nutrient was found to be P for Scenario 1 and $\mathrm{N}$ for Scenarios 2 and 3. The calculations were therefore performed for P reaching the desired MTR value in Scenario 1 and for $\mathrm{N}$ reaching the desired value for Scenarios 2 and 3. Consequently, in the P limiting Scenario 1, the $\mathrm{N}$ concentration remained above target with $5.39 \mathrm{mg} \mathrm{N} / \mathrm{L}$, while in the $\mathrm{N}$ limiting Scenarios 2 and 3 the $\mathrm{P}$ concentration remained above target. The latter two also did not comply with current EU effluent discharge requirements of $1 \mathrm{mg} \mathrm{P} / \mathrm{L}$. Consequently, the desired effluent values for both $\mathrm{N}$ and $\mathrm{P}$ could not be reached simultaneously.

In Scenario 3, a symbiotic relationship between microalgae and heterotrophs was assumed to develop. The $\mathrm{O}_{2}$ production by the microalgae and the $\mathrm{O}_{2}$ consumption by the heterotrophs were balanced, by adjusting the fraction of $\mathrm{N}$ that was removed by combined nitrification and denitrification 
and the fraction that was assimilated by microalgae. Figure 2 shows that the $\mathrm{O}_{2}$ in the system was balanced when $70 \%$ of the $\mathrm{NH}_{4}^{+}$was converted by the heterotrophs (nitrification-denitrification) and the remaining $30 \%$ by the microalgae. With this balance, the microalgae supply all $\mathrm{O}_{2}$ for the heterotrophs, and aeration is theoretically not needed. However, it can also be seen from Figure 2 that the $\mathrm{CO}_{2}$ production and consumption could not be balanced at the same time. Approximately $40 \%$ additional $\mathrm{CO}_{2}$ needs to be supplied or fixed by the microalgae from the air.

Figure 2. The consumption of $\mathrm{CO}_{2}$ by microalgae alongside the production of $\mathrm{CO}_{2}$ by heterotrophs, and the production of $\mathrm{O}_{2}$ by microalgae alongside the consumption of $\mathrm{O}_{2}$ by heterotrophs in the symbiotic system of Scenario 3. The amounts are expressed in gram per person equivalent (PE) per day.

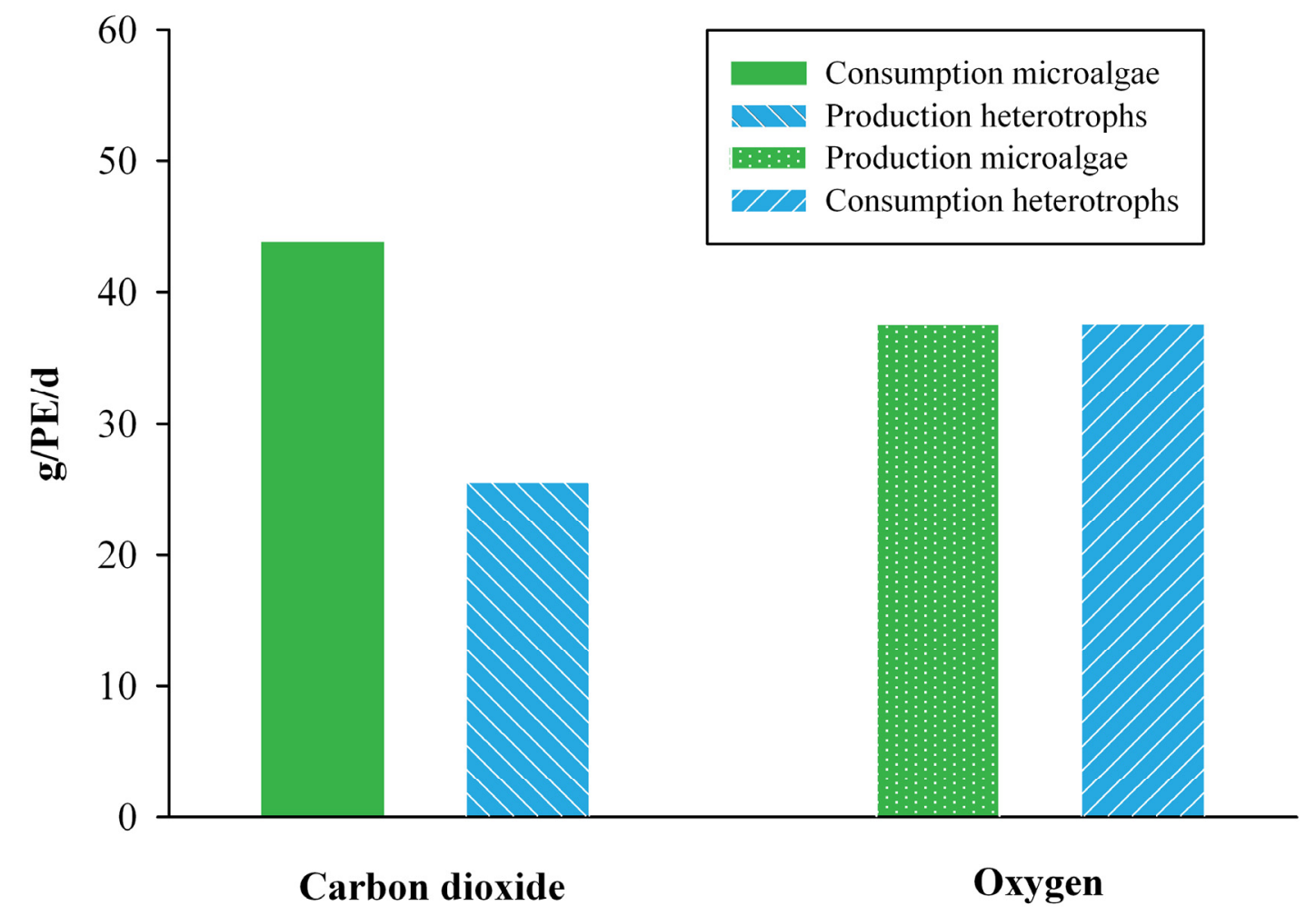

Figure 3 shows the amount of activated sludge and microalgal biomass produced in the three different scenarios. The microalgal biomass per PE was based on the calculated microalgal biomass production of $24 \mathrm{~g} / \mathrm{m}^{2} / \mathrm{d}$ in Scenario 1 and $28 \mathrm{~g} / \mathrm{m}^{2} / \mathrm{d}$ in Scenarios 2 and 3. In Scenario 1 similar amounts of activated sludge and microalgal biomass were produced. Scenario 2 had the largest microalgal biomass production of $59 \mathrm{~g} / \mathrm{PE} / \mathrm{d}$, because larger amounts of nutrients needed to be assimilated in this scenario. 
Figure 3. The microalgal biomass and activated sludge in the three scenarios for a WWTP of 100,000 inhabitants in the Netherlands from May to October. The amount of activated sludge is expressed in grams volatile suspended solids (VSS) and the amount of microalgae in grams dry weight, both per person equivalent $(\mathrm{PE})$ per day.

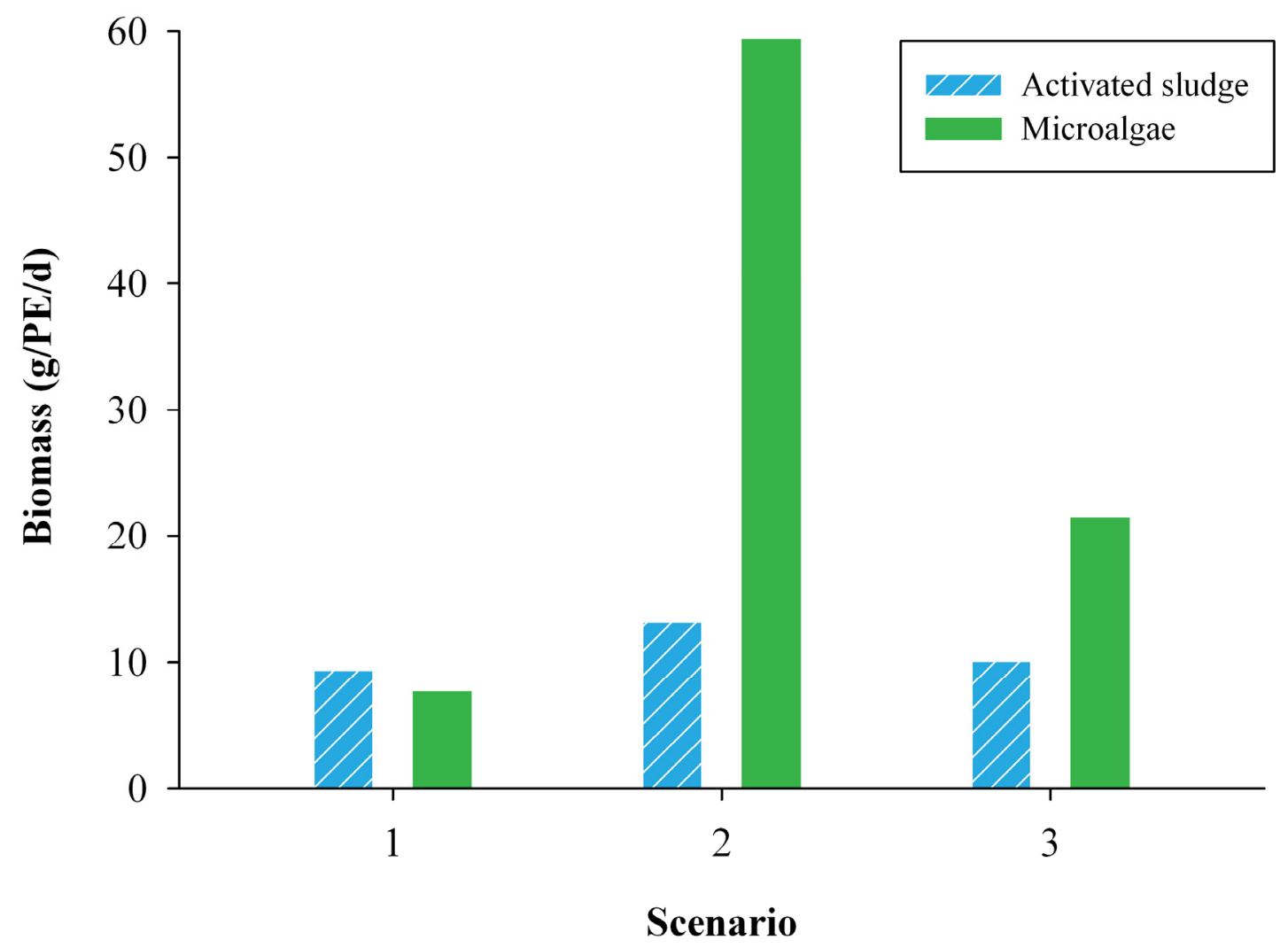

\section{Discussion}

\subsection{Effluent Concentrations}

The results of this scenario analysis showed that it was not possible to simultaneously remove the $\mathrm{N}$ and $\mathrm{P}$ in the wastewater to the target values of $2.2 \mathrm{mg} \mathrm{N} / \mathrm{L}$ and $0.15 \mathrm{mg} \mathrm{P} / \mathrm{L}$. In the post-treatment scenario $\mathrm{P}$, while in Scenarios 2 and $3 \mathrm{~N}$ was limiting the microalgae growth. Indeed, given the ratio of $\mathrm{N}: \mathrm{P}$ in wastewater, $\mathrm{N}$ will always be the limiting nutrient, if the molar ratio of $\mathrm{C}: \mathrm{N}: \mathrm{P}$ of 100:12:1 represents the real average elemental composition of microalgae grown in such systems. However, elemental composition in microalgae is known to be highly variable. Compositions with C:P ratios between 34:1 and 418:1, and $\mathrm{N}: \mathrm{P}$ ratios between 3.5:1 and 38:1 are reported in literature for different species of microalgae [20,22]. Also the growth conditions, with respect to nutrient and/or light limitation, influence the elemental composition. Molar N:P ratios as low as 3:1 have been reported under $\mathrm{N}$ limiting conditions, while under conditions of $\mathrm{P}$ limitation a N:P ratio of 100:1 is possible [23,24]. At low growth rates, the N:P ratio of the biomass composition can sometimes match the supply ratio. Especially luxury uptake of $\mathrm{P}$ with storage as polyphosphate, is known to take place in microalgae $[25,26]$. This luxury uptake might make it possible to not only achieve MTR quality with respect to N, but also with respect to $P$. 
In the scenario analysis only $\mathrm{N}$ and $\mathrm{P}$ removal by microalgal assimilation was taken into account. Additional removal of $\mathrm{P}$ by precipitation with cations like $\mathrm{Ca}^{2+}$ and $\mathrm{Mg}^{2+}$ is also possible. This precipitation occurs at higher $\mathrm{pH}$ levels caused by microalgae changing the $\mathrm{CO}_{2} / \mathrm{HCO}_{3}{ }^{-} / \mathrm{CO}_{3}{ }^{2-}$ equilibrium when more $\mathrm{CO}_{2}$ is taken up than can be supplied via absorption from the atmosphere $[9,26]$. With such a $\mathrm{pH}$ rise expected within the biofilm, it is likely that in practice a larger P removal occurs than was calculated.

\subsection{Area Requirement}

This study found area requirements for the three scenarios between 0.32 and $2.1 \mathrm{~m}^{2} / \mathrm{PE}$. A conventional WWTP is estimated to have an area requirement around $0.2-0.4 \mathrm{~m}^{2} / \mathrm{PE}$. Hence, with $0.32 \mathrm{~m}^{2} / \mathrm{PE}$, the microalgal post-treatment requires a similar area to that of the activated sludge plant. The two-stage system of Scenario 2 requires the largest area of $2.1 \mathrm{~m}^{2} / \mathrm{PE}$. However, the first activated sludge stage will be considerably smaller than in a conventional WWTP, because nitrification is absent. In addition, more sludge is produced, and this sludge will have a higher energy value. This implies that more methane can be produced when digesting the sludge anaerobically.

The symbiotic system of Scenario 3 has an area requirement of $0.76 \mathrm{~m}^{2} / \mathrm{PE}$, which is smaller than the area of the system of Scenario 2, and similar to the conventional WWTP combined with microalgal post-treatment in Scenario 1. Moreover, this system has the advantage that the $\mathrm{O}_{2}$ production by microalgae and $\mathrm{O}_{2}$ consumption by heterotrophs can be balanced. This balance implies no need for an external oxygen supply, giving energy and cost savings. Although very attractive, the technology required to support a symbiotic biofilm system still needs to be developed.

The area requirements are based on the calculated uptake capacities of $1.85 \mathrm{~g} \mathrm{~N} / \mathrm{m}^{2} / \mathrm{d}$ and $0.34 \mathrm{~g} \mathrm{P} / \mathrm{m}^{2} / \mathrm{d}$ in the post-treatment scenario and $2.2 \mathrm{~g} \mathrm{~N} / \mathrm{m}^{2} / \mathrm{d}$ and $0.41 \mathrm{~g} \mathrm{P} / \mathrm{m}^{2} / \mathrm{d}$ in Scenarios 2 and 3 . These calculated uptake capacities are higher than the $0.1-0.6 \mathrm{~g} \mathrm{~N} / \mathrm{m}^{2} / \mathrm{d}$ and $0.006-0.09 \mathrm{~g} \mathrm{P} / \mathrm{m}^{2} / \mathrm{d}$ measured in lab-scale biofilm systems [13,14], but lower than the $0.7-2.1 \mathrm{~g} \mathrm{P} / \mathrm{m}^{2} / \mathrm{d}$ measured in other pilot scale microalgal biofilms systems $[11,27]$. This indicates that the calculated uptake capacities in this study can be considered a good average estimation.

The area requirement calculated for the different microalgal systems depends on the elemental composition of microalgal biomass, as well as on the irradiance and the photosynthetic efficiency. As mentioned above, the elemental composition can vary in microalgae. Clearly a higher $\mathrm{N}$ and $\mathrm{P}$ content in the microalgae will result in a lower area requirement, while a lower content will increase the required area. This again illustrates the importance of knowing the real elemental composition of the microalgae when growing on wastewater.

The effect of irradiance on the area requirement can only be changed by either moving the system to another location, or by applying artificial illumination. However, the addition of artificial light yields no substantial area reduction. If all produced biomass, both activated sludge as well as microalgal biomass, would be converted into biogas to produce electricity for artificial light, the area reduction for the three scenarios is at most $0.8 \%$ (see Appendix B). This extremely low reduction is related to the energy losses in the process of methanogenesis, in converting biogas into electricity, electricity into light and light into new biomass via photosynthesis. Clearly these large scale microalgae based processes can only be fueled by sunlight. 
In this analysis the oxygen quantum efficiency was assumed to be $0.05 \mathrm{~mol} \mathrm{O}_{2} / \mathrm{mol}$ photons. This value is not reached in horizontal microalgal systems, but has been reached in vertical panel photobioreactors [17]. This efficiency has been determined with light as the limiting substrate. However, it is likely that $\mathrm{CO}_{2}$ limitation will occur when the biofilm is only exposed to ambient air. Modeling of microalgal biofilms has shown that $\mathrm{CO}_{2}$ limitation can easily occur, the level of limitation depending on the bulk $\mathrm{pH}$ and alkalinity [28]. Therefore, the assumed efficiency can only be reached in a vertical biofilm system, if $\mathrm{CO}_{2}$ limitation can be prevented. Using heterotrophic microorganisms to directly supply the $\mathrm{CO}_{2}$ to the microalgae as in Scenario 3, may therefore be a very attractive way to accomplish this.

\subsection{Seasonal Variation in Temperature and Light Intensity}

Both microalgal growth and uptake of $\mathrm{N}$ and $\mathrm{P}$ decrease at lower temperatures and light intensity [29]. Therefore, the capacity of the microalgal system will change throughout the day and the seasons. Low uptake of nutrients by microalgae during winter may be one of the main limitations of the application of microalgal wastewater treatment systems in a country like the Netherlands. In this scenario analysis, the system was assumed to be running only in the tourist season, from May until October. The application of the microalgal system in places where a much higher capacity is needed during summer is the most interesting application of this technology in The Netherlands. The microalgal system will provide additional capacity during summer, whereas during winter the existing WWTP capacity will be sufficient. Such a microalgal system may be applied on the islands in the Wadden Sea of the Netherlands, being a tourist location during summer. On the island Ameland for example, wastewater production during summer can be more than three times the amount during the rest of the year. With these conditions a microalgal biofilm system is an interesting option to treat the additional wastewater in summer, instead of increasing the size of the wastewater treatment plant to be able to treat the summer wastewater load.

\subsection{Daily Variation in Light Intensity}

The microalgae production was based on the total irradiation received in five months, and therefore the diurnal light cycle was not taken into account. In general, uptake of $\mathrm{N}$ and $\mathrm{P}$ by microalgae changes throughout the day and is faster during daytime than in the dark [24,25]. N-limited microalgae, on the other hand, are known to take up either $\mathrm{NO}_{3}{ }^{-}$or $\mathrm{NH}_{4}{ }^{+}$in the dark. Uptake of $\mathrm{NH}_{4}{ }^{+}$can be more than $50 \%$ of the daylight value in N-limited microalgae [30]. Consequently, when $\mathrm{N}$ is the limiting nutrient for microalgae in the treatment of municipal wastewater, considerable uptake of $\mathrm{N}$ during darkness might be expected. In addition, the wastewater loading rate of $\mathrm{N}$ and $\mathrm{P}$ is expected to be lower during the night, possibly compensating for the reduced nutrient uptake.

\subsection{Application of Microalgal Biomass}

When using microalgal biofilm systems in wastewater treatment, substantial amounts of microalgal biomass are produced. In Scenario 1 the microalgal biomass production was $24 \mathrm{~g} / \mathrm{m}^{2} / \mathrm{d}$ based on the consumption of $\mathrm{NO}_{3}{ }^{-}$and in Scenarios 2 and 3 the production was $28 \mathrm{~g} / \mathrm{m}^{2} / \mathrm{d}$ based on the 
consumption of $\mathrm{NH}_{4}{ }^{+}$. These biomass productions are slightly higher than biomass production of $11-18 \mathrm{~g} / \mathrm{m}^{2} / \mathrm{d}$ measured in pilot photobioreactors [31,32] and in the range of biomass production of $24-31 \mathrm{~g} / \mathrm{m}^{2} / \mathrm{d}$ measured in other biofilm pilot systems [11,27]. With this biomass production, a WWTP for 100,000 inhabitants with the microalgal post-treatment of Scenario 1 produces 200 ton (dry weight) microalgal biomass during the five summer months of operation. In Scenarios 2 and 3 this amount of biomass is even larger. With such a substantial amount of biomass, it is important to find an efficient way to harvest the biomass, and a proper destination.

To ensure an actively growing biofilm, and to prevent washout of valuable biomass with the effluent, the biofilm will need to be harvested regularly. This regular harvesting will reduce respiratory biomass losses or even cell death, which otherwise would lead to release of $\mathrm{N}$ and $\mathrm{P}$ from the biofilm. Two ways of harvesting can be distinguished, passive and active. Passive harvesting entails collecting the microalgal biomass that naturally detaches from the top of the biofilm when it ages. This might involve the addition of a settler tank, resulting in extra area requirement. Active harvesting techniques currently applied to remove biofilms in other systems include $\mathrm{pH}$ shock [33], backwashing and scraping. Active harvesting appears more attractive as it gives the possibility to harvest very regularly, hereby reducing the respiratory losses as much as possible.

Nitrogen was shown to be the limiting nutrient when integrating microalgal biofilms in the wastewater treatment (Scenarios 2 and 3). In this case, it might be possible to accumulate lipids in the microalgal biomass, as microalgae start to accumulate these under conditions of N-limitation [34,35]. To achieve this $\mathrm{N}$-starvation and induce lipid accumulation the $\mathrm{C}: \mathrm{N}$ ratio should be twice as high as was assumed in the scenario analysis. Although this increased ratio would result in an area requirement twice as large, the amount of produced biomass will also be doubled and thus larger amounts of lipids may be produced. In Scenario 1 these lipids would approximately amount to 79 ton during the five summer months of operation (see Appendix C). However, further research is still needed to induce the accumulation of specific desired lipids, to obtain a stable (mixed) culture of the desired species in the system, and to set up the biorefinery needed to extracts these lipids as well as valorize the remaining biomass constituent [30,31].

Depending on the microalgal biomass composition other products might also be possible. Using the biomass as fertilizer is very attractive but is only possible when no heavy metals or other recalcitrant compounds are present in the wastewater and accumulated by microalgae. Anaerobic digestion for biogas production is another possibility, although afterwards still autotrophic $\mathrm{N}$ and $\mathrm{P}$ removal or recovery will be necessary. The $\mathrm{CO}_{2}$ that is produced during digestion might be recycled to the microalgal biofilm system as an additional $\mathrm{CO}_{2}$ supply [36,37].

\section{Conclusions}

This study investigated the potential of a hypothetical microalgal biofilm system as a seasonal wastewater treatment system in the Netherlands. The analysis showed that the area requirement of the microalgal biofilm system was $0.32 \mathrm{~m}^{2} / \mathrm{PE}$ for a post-treatment system, $2.10 \mathrm{~m}^{2} / \mathrm{PE}$ for a two stage wastewater treatment system and $0.76 \mathrm{~m}^{2} / \mathrm{PE}$ for a one-stage symbiotic system. In addition, it was found that microalgae growing on wastewater treatment plant effluent are P limited and microalgae growing on untreated or partially treated wastewater are $\mathrm{N}$ limited. The microalgae will produce a 
substantial amount of biomass. For the application of microalgal biofilms in countries such as the Netherlands, further research should look into the effect of the daily variation of both the wastewater flows and of the irradiation and temperature. In addition, the destination of the produced biomass is an important topic for future studies. Finally, real (pilot) tests should be performed to establish if indeed a photosynthetic efficiency of $0.05 \mathrm{~mol} \mathrm{O}_{2} / \mathrm{mol}$ photons can be reached and whether $\mathrm{CO}_{2}$ limitation will occur.

\section{Acknowledgements}

This work was performed in the TTIW-cooperation framework of Wetsus, Centre of Excellence for Sustainable Water Technology [38]. Wetsus is funded by the Dutch Ministry of Economic Affairs, the European Union Regional Development Fund, the Province of Fryslân, the City of Leeuwarden and the EZ/Kompas program of the "Samenwerkingsverband Noord-Nederland". The authors like to thank the participants of the research theme "Advanced waste water treatment" and the steering committee of STOWA for the discussions and their financial support.

\section{References}

1. Brock, T.D.; Madigan, M.T.; Martinko, J.M.; Parker, J. Biology of Microorganisms, 9th ed.; Prentice-Hall: Upper Saddle River, NJ, USA, 2000.

2. Halterman, S.G.; Toetz, D.W. Kinetics of nitrate uptake by freshwater algae. Hydrobiologia 1984, 114, 209-214.

3. Collos, Y.; Vaquer, A.; Souchu, P. Acclimation of nitrate uptake by phytoplankton to high substrate levels. J. Phycol. 2005, 41, 466-478.

4. Eppley, R.W.; Rogers, J.N.; McCarthy, J.J. Half-Saturation constants for uptake of nitrate and ammonium by marine phytoplankton. Limnol. Oceanogr. 1969, 14, 912-920.

5. Hwang, S.J.; Havens, K.E.; Steinman, A.D. Phosphorus kinetics of planktonic and benthic assemblages in a shallow subtropical lake. Freshw. Biol. 1998, 40, 729-745.

6. Stevenson, R.J.; Bothwell, M.L.; Lowe, R.L. Algal Ecology: Freshwater Benthic Ecosystems; Academic Press Elsevier: San diego, CA, USA, 1996.

7. Di Pippo, F.; Ellwood, N.; Guzzon, A.; Siliato, L.; Micheletti, E.; de Philippis, R.; Albertano, P. Effect of light and temperature on biomass, photosynthesis and capsular polysaccharides in cultured phototrophic biofilms. J. Appl. Phycol. 2011, 24, 1-10.

8. Sekar, R.; Nair, K.V.K.; Rao, V.N.R.; Venugopalan, V.P. Nutrient dynamics and successional changes in a lentic freshwater biofilm. Freshwater Biol. 2002, 47, 1893-1907.

9. Roeselers, G.; Loosdrecht, M.; Muyzer, G. Phototrophic biofilms and their potential applications. J. Appl. Phycol. 2008, 20, 227-235.

10. Schumacher, G.; Blume, T.; Sekoulov, I. Bacteria reduction and nutrient removal in small wastewater treatment plants by an algal biofilm. Water Sci. Technol. 2003, 47, 195-202.

11. Craggs, R.J.; Adey, W.H.; Jenson, K.R.; St. John, M.S.; Green, F.B.; Oswald, W.J. Phosphorous removal from wastewater using algal turf scrubber. Water Sci. Technol. 1996, 33, 191-198. 
12. Shi, J.; Podola, B.; Melkonian, M. Removal of nitrogen and phosphorus from wastewater using microalgae immobilized on twin layers: An experimental study. J. Appl. Phycol. 2007, 19, 417-423.

13. De Godos, I.; González, C.; Becares, E.; García-Encina, P.; Muñoz, R. Simultaneous nutrients and carbon removal during pretreated swine slurry degradation in a tubular biofilm photobioreactor. Appl. Microbiol. Biotechnol. 2009, 82, 187-194.

14. González, C.; Marciniak, J.; Villaverde, S.; León, C.; García, P.A.; Munoz, R. Efficient nutrient removal from swine manure in a tubular biofilm photo-bioreactor using algae-bacteria consortia. Water Sci. Technol. 2008, 58, 95-102.

15. Ley, A.C.; Mauzerall, D.C. Absolute absorption cross-sections for Photosystem II and the minimum quantum requirement for photosynthesis in Chlorella vulgaris. BBA-Bioenergetics 1982, 680, 95-106.

16. Bjorkman, O.; Demmig, B. Photon yield of $\mathrm{O}_{2}$ evolution and chlorophyll fluorescence characteristics at $77 \mathrm{~K}$ among vascular plants of diverse origins. Planta 1987, 170, 489-504.

17. Qiang, H.; Faiman, D.; Richmond, A. Optimal tilt angles of enclosed reactors for growing photoautotrophic microorganisms outdoors. J. Ferment. Bioeng. 1998, 85, 230-236.

18. Duboc, P.; Marison, I.; Stockar, U.V. Quantitative calorimetry and biochemical engineering. In Handbook of Thermal Analysis and Calorimetry; Kemp, R.B., Ed.; Elsevier: Amsterdam, The Netherlands, 1999; Volume 4.

19. Healey, F.P. Inorganic nutrient uptake and deficiency in algae. Crit. rev. microbiol. 1973, 3, 69-113.

20. Ahlgren, G.; Gustafsson, I.B.; Boberg, M. Fatty-acid content and chemical-Composition of fresh-water microalgae. J. Phycol. 1992, 28, 37-50.

21. Metcalf, I.; Eddy, H. Wastewater Engineering: Treatment and Reuse, 4th ed.; McGraw-Hill: Columbus, OH, USA, 2003.

22. Ho, T.Y.; Quigg, A.; Finkel, Z.V.; Milligan, A.J.; Wyman, K.; Falkowski, P.G.; Morel, F.M.M. The elemental composition of some marine phytoplankton. J. Phycol. 2003, 39, 1145-1159.

23. Goldman, J.C.; McCarthy, J.J.; Peavey, D.G. Growth rate influence on the chemical composition of phytoplankton in oceanic waters. Nature 1979, 279, 210-215.

24. Elrifi, I.R.; Turpin, D.H. Steady-state luxury consumption and the concept of optimum nutrient ratios: A study with phosphate and nitrate limited Selenastrum minutum (Chlorophyta). J. Phycol. 1985, 21, 592-602.

25. Klausmeier, C.A.; Litchman, E.; Simon, A.L. Phytoplankton growth and stoichiometry under multiple nutrient limitation. Limnol. Oceanogr. 2004, 49, 1463-1470.

26. Powell, N.; Shilton, A.N.; Pratt, S.; Chisti, Y. Factors Influencing luxury uptake of phosphorus by microalgae in waste stabilization ponds. Envir. Sci. Technol. 2008, 42, 5958-5962.

27. Christenson, L.B.; Sims, R.C. Rotating algal biofilm reactor and spool harvester for wastewater treatment with biofuels by-products. Biotechnol. Bioeng. 2012, doi: 10.1002/bit.24451.

28. Liehr, S.K.; Eheart, J.W.; Suidan, M.T. A modeling study of the effect of $\mathrm{pH}$ on carbon limited algal biofilms. Water Res. 1988, 22, 1033-1041.

29. Goldman, J.C.; Carpenter, E.J. A Kinetic approach to the effect of temperature on algal growth. Limnol. Oceanogr. 1974, 19, 756-766. 
30. Vona, V.; Rigano, V.D.M.; Esposito, S.; Carillo, P.; Carfagna, S.; Rigano, C. Growth, photosynthesis, and respiration of Chlorella sorokiniana after N-starvation. Interactions between light, $\mathrm{CO}_{2}$ and $\mathrm{NH}_{4}^{+}$supply. Physiol. Plantarum 1999, 105, 288-293.

31. Hulatt, C.J.; Thomas, D.N. Energy efficiency of an outdoor microalgal photobioreactor sited at mid-temperature latitude. Bioresource technol. 2011, 102, 6687-6695.

32. Min, M.; Wang, L.; Li, Y.; Mohr, M.J.; Hu, B.; Zhou, W.; Chen, P.; Ruan, R. Cultivating Chlorella sp. in a pilot-scale photobioreactor using centrate wastewater for microalga biomass production and wastewater nutrient removal. Appl. Biochem. Biotech. 2011, 165, 123-137.

33. Knuckey, R.M.; Brown, M.R.; Robert, R.; Frampton, D.M.F. Production of microalgal concentrates by flocculation and their assessment as aquaculture feeds. Aquacult. Eng. 2006, 35, 300-313.

34. Converti, A.; Casazza, A.A.; Ortiz, E.Y.; Perego, P.; del Borghi, M. Effect of temperature and nitrogen concentration on the growth and lipid content of Nannochloropsis oculata and Chlorella vulgaris for biodiesel production. Chem. Eng. Process. 2009, 48, 1146-1151.

35. Solovchenko, A.; Khozin-Goldberg, I.; Didi-Cohen, S.; Cohen, Z.; Merzlyak, M. Effects of light intensity and nitrogen starvation on growth, total fatty acids and arachidonic acid in the green microalga Parietochloris incisa. J. Appl. Phycol. 2008, 20, 245-251.

36. Muñoz, R.; Guieysse, B. Algal-bacterial processes for the treatment of hazardous contaminants: A review. Water Res. 2006, 40, 2799-2815.

37. Mussgnug, J.H.; Klassen, V.; Schlüter, A.; Kruse, O. Microalgae as substrates for fermentative biogas production in a combined biorefinery concept. J. Biotechnol. 2010, 150, 51-56.

38. Wetsus Centre of Excellence for Sustainable Water Technology Home Page. Available online: http://www.wetsus.nl (accessed on 16 April 2012).

(C) 2012 by the authors; licensee MDPI, Basel, Switzerland. This article is an open access article distributed under the terms and conditions of the Creative Commons Attribution license (http://creativecommons.org/licenses/by/3.0/). 